\title{
CLOSURE REPORT FOR CORRECTIVE ACTION UNIT 210: STORAGE AREAS AND CONTAMINATED MATERIAL, NEVADA TEST SITE, NEVADA
}

\author{
Prepared for: \\ U.S. Department of Energy \\ National Nuclear Security Administration \\ Nevada Site Office \\ Work Performed Under Contract No. DE-AC08-96NV11718
}

Controlled Copy No:

Revision: 0

June 2004 



\section{CLOSURE REPORT FOR CORRECTIVE ACTION UNIT 210: STORAGE AREAS AND CONTAMINATED MATERIAL, NEVADA TEST SITE, NEVADA}

$$
\text { Approved By: } \frac{\text { Sabine Curtis }}{\text { Janet Appenzeller-Wing, Project Manager }}
$$

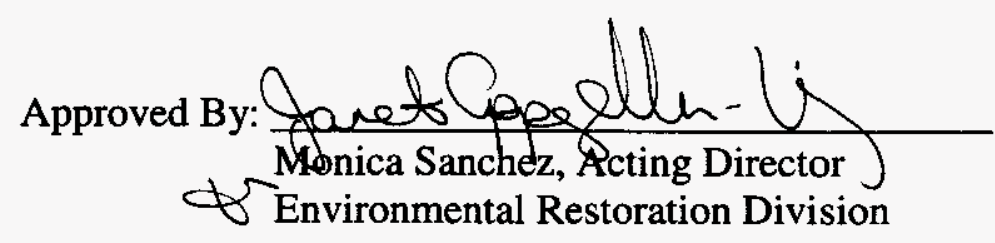

Date: $\quad 6-21-04$

Date: $6.21 \cdot 04$ 
$-$

$-$

$-$

$\rightarrow$

,

$-$

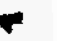




\section{TABLE OF CONTENTS}

ACRONYMS AND ABBREVIATIONS .................................................................. vii

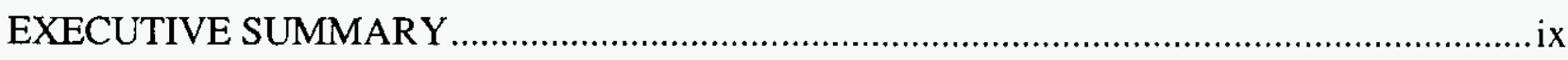

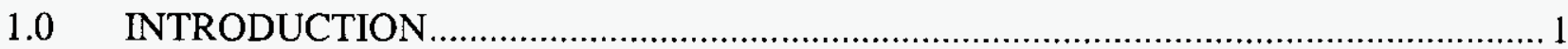

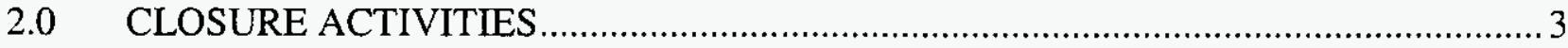

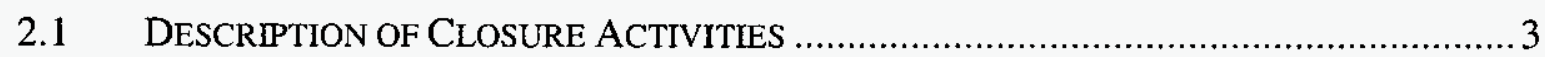

2.1.1 Preplanning and Site Preparation .................................................... 3

2.2 Site CHARACTERIZATION ACTIVITIES............................................................ 3

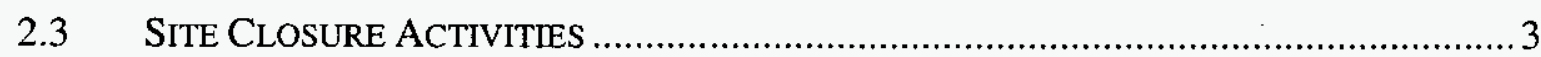

2.3.1 CAS 10-23-01: Metal Debris; RAD ................................................... 3

2.3.2 CAS 12-28-03: U-12a Portal Housekeeping Debris ................................. 3

2.3.3 CAS 12-99-10: Storage Flatcar ............................................................. 4

2.3.4 CAS 15-18-01: Chemical Storage Drums (4) ....................................... 4

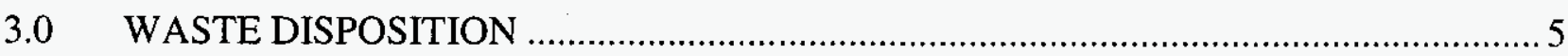

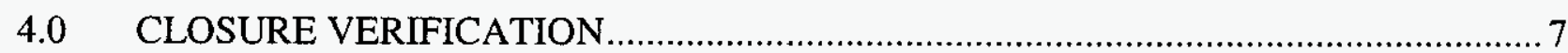

5.0 SUMMARY AND RECOMMENDATIONS ...................................................

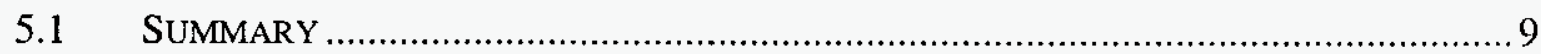

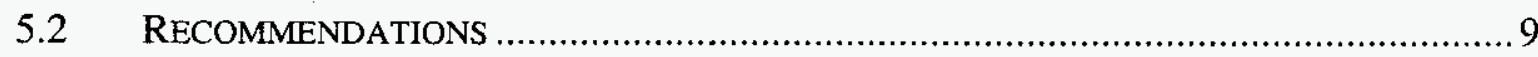

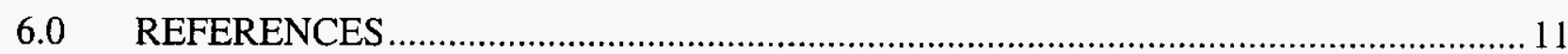

\section{FIGURES}

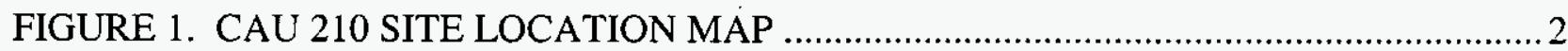

\section{APPENDICES}

APPENDIX A: SECTORED HOUSEKEEPING SITE CLOSURE VERIFICATION FORMS APPENDIX B: NATIONAL ENVIRONMENTAL POLICY ACT EVALUATION CHECKLIST

APPENDIX C: CORRECTIVE ACTION UNIT 210 FFACO MODIFICATION COORESPONDENCE

LIBRARY DISTRIBUTION LIST 


\section{THIS PAGE INTENTIONALLY LEFT BLANK}




\section{ACRONYMS AND ABBREVIATIONS}

BN Bechtel Nevada

CAS Corrective Action Site(s)

CAU Corrective Action Unit

FFACO Federal Facility Agreement and Consent Order

NDEP Nevada Division of Environmental Protection

NNSA/NSO U.S. Department of Energy, National Nuclear Security Administration Nevada Site Office

NTS Nevada Test Site 


\section{EXECUTIVE SUMMARY}

Corrective Action Unit (CAU) 210, Storage Areas and Contaminated Material, is identified in the Federal Facility Agreement and Consent Order (FFACO, 1996). This CAU consists of four Corrective Action Sites (CASs) located in Areas 10, 12, and 15 of the Nevada Test Site. Of the four CASs originally included in CAU 210, two were transferred to other CAUs as detailed below. At the remaining two CASs, closure activities consisted of inspecting, determining, and documenting that the waste originally identified in the FFACO is no longer present at those sites. CAU 210 closure activities included the following:

- CAS 10-23-01, Metal Debris (RAD): CAS was transferred to CAU 286. No further action was taken.

- CAS 12-28-03, U-12a Portal Housekeeping Debris: CAS was transferred to CAU 5000. No further action was taken.

- CAS 12-99-10, Storage Flatcar: CAS was inspected determining waste is no longer present. No further action was taken.

- CAS 15-18-01, Chemical Storage Drums (4): CAS was inspected determining waste is no longer present. No further action was taken.

In a letter dated April 15, 2004, the Nevada Division of Environmental Protection (NDEP) approved the FFACO modification to move of CAS 10-23-01 (Metal Debris; RAD) out of CAU 210 and into CAU 286, Lead/Chemical/Spill Sites and Material Dumps, for closure at a later date. For this reason, no further action was taken to close this CAS.

Also, in a letter dated May 24, 2004, the NDEP approved the FFACO modification to designate CAS 12-28-03 (U-12a Portal Housekeeping Debris) as an historical site, and as such be moved out of CAU 210 and into CAU 5000, Archived Corrective Action Sites. For this reason, no further action was taken to close this CAS. 
Date: June 2004

\section{THIS PAGE INTENTIONALLY LEFT BLANK}

-1
-

$\rightarrow$

$-$

$-$ 


\subsection{INTRODUCTION}

This report documents that the closure activities conducted for Corrective Action Unit (CAU) 210, Storage Areas and Contaminated Material, meet the approved closure standards. CAU 210 is listed in Appendix III of the Federal Facility Agreement and Consent Order (FFACO, 1996) and consists of the following four Corrective Action Sites (CASs) located in Areas 10, 12, and 15 of the Nevada Test Site (NTS) (Figure 1):

- CAS 10-23-01: Metal Debris (RAD)

- CAS 12-28-03: U-12a Portal Housekeeping Debris

- CAS 12-99-10: Storage Flatcar

- CAS 15-18-01: Chemical Storage Drums (4)

In a letter dated April 15, 2004, the Nevada Division of Environmental Protection (NDEP) approved a FFACO modification to move CAS 10-23-01, Metal Debris (RAD), out of CAU 210 and into CAU 286, Lead/Chemical/Spill Sites and Material Dumps, for closure at a later date (see Appendix C). For this reason, no further action was taken to close this site.

CAS 12-28-03, U-12a Portal Housekeeping Debris, was evaluated and classified as an historical site. In a letter dated May 24, 2004, the NDEP approved the FFACO modification to move CAS 12-28-03, U-12a Portal Housekeeping Debris, out of CAU 210 and into CAU 5000, Archived Corrective Action Sites (see Appendix C). For this reason, no further action was taken to close this site.

Closure activities at the remaining two CASs consisted of identifying those sites and documenting that the waste originally listed in the FFACO is no longer present on those sites. Copies of the Sectored Housekeeping Site Closure Verification Forms for those two CASs are included in Appendix A. A copy of the National Environmental Policy Act Evaluation Checklist that includes CAU 210 is included in Appendix B. 
Date: Junc 2004

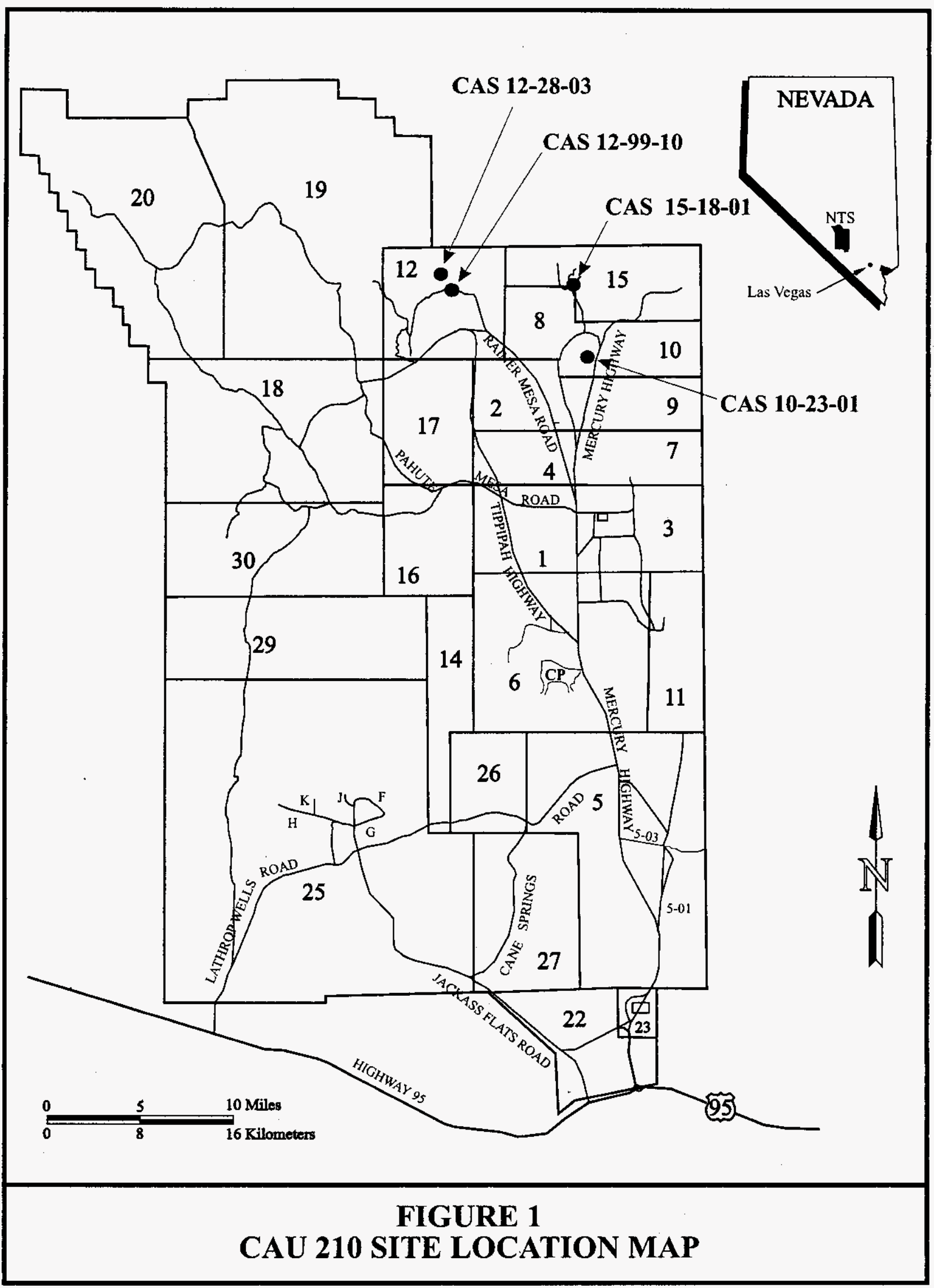




\subsection{CLOSURE ACTIVITIES}

This section details the specific corrective action activities completed for CAU 210: Storage Areas and Contaminated Material.

\subsection{DESCRIPTION OF CLOSURE ACTIVITIES}

\subsubsection{Preplanning and Site Preparation}

Planning documents prepared prior to the beginning of closure activities include the following:

- Sectored Clean-up Work Plan For Housekeeping Category Waste Sites (U.S. Department of Energy, National Nuclear Security Administrations Nevada Site Office [NNSA/NSO], 2003).

- Generic Field Management Plan for Housekeeping Category Waste Sites (Bechtel Nevada [BN], 2003).

- Site-Specific Health and Safety Plan for Corrective Action Units 167, 210, 286, 390, \& 395 Housekeeping Sites, Nevada Test Site, Nevada (BN, 2003).

- NNSA/NSO Real Estate/Operation Permit.

\subsection{SITE CHARACTERIZATION ACTIVITIES}

During the initial site visits for CAU 210 it was noted that the waste originally described in the FFACO for two CASs is no longer present at those sites. Therefore, no site characterization activities other than documenting current site conditions were performed.

\subsection{SITE CLOSURE ACTIVITIES}

Appendix A includes the Housekeeping Site Closure Verification Forms that present site information and include before and after site photographs.

\subsubsection{CAS 10-23-01: Metal Debris; RAD}

Due to a reorganization of the Housekeeping CASs, this CAS was transferred out of CAU 210 and into CAU 286, Lead/Chemical/Spill Sites and Material Dumps. A FFACO modification to transfer CAS 10-23-01 from CAU 210 into CAU 286 was approved by the NDEP in a letter dated April 15, 2004. A copy of the NDEP approval letter is included in Appendix C.

\subsubsection{CAS 12-28-03: U-12a Portal Housekeeping Debris}

Several rusted cans from spent military smoke pots are located at the U-12a portal. Based on an evaluation by an archaeologist from the Desert Research Institute, the site was recommended for designation as an historical site. For this reason, no action was taken to close this site, and a FFACO modification to transfer CAS 12-28-03 from CAU 210 to CAU 5000, Archived Corrective Action Sites, was approved by the NDEP in a letter dated May 24, 2004. A copy of the NDEP approval letter is included in Appendix C. 


\subsubsection{CAS 12-99.10: Storage Flatcar}

The site as identified in the FFACO indicates that a railroad flatcar was located in the vicinity of the Area 12 "L" storage yard. Field investigation revealed that, although there were no flatcars noted in the Area 12 Camp vicinity, there are several railroad boxcars currently in use as storage containers for Area 12 operations. Based on this information, no further action was taken for this CAS. No further action is required at this site.

\subsubsection{CAS 15-18-01: Chemical Storage Drums (4)}

The drums originally identified in Appendix II of the FFACO (1996) were not present during the site visit to the Area 15 former Climax Hoist facility. The drums were identified originally as being mounted on a structural steel frame that was positioned on a large concrete pad greater than 1 foot thick. Visual inspection of the concrete pad did not indicate evidence of leakage or staining. In addition, the concrete pad did not exhibit any defects such as cracks or holes. Based on the visual inspection, there is no evidence of leakage from the drums and no further action was taken for this CAS. Site conditions were documented with photographs and field notes. No further action is required at this site. 


\subsection{WASTE DISPOSITION}

No waste was generated during the closure of CAU 210. 
 \\ THIS PAGE INTENTIONALLY LEFT BLANK}




\subsection{CLOSURE VERIFICATION}

None of the CASs in CAU 210 required verification sampling. At CAS 12-99-10 (Storage Flatcar) and CAS 15-18-01 (Chemical Storage Drums [4]), closure verification consisted of visually inspecting the sites to verify that the waste originally identified is no longer present, and documenting the current site conditions. Copies of the Sectored Housekeeping Site Closure Verification Forms for CAS 12-99-10 and 15-18-01 are included in Appendix A. 


\subsection{SUMMARY AND RECOMMENDATIONS}

\subsection{SUMMARY}

Closure activities at CAS 10-23-01 and 12-28-03 consisted of taking no further action. CAS 10-23-01 was transferred from CAU 210 to CAU 286 for closure at a later date. CAS 12-28-03 was reclassified as an historical site and transferred from CAU 210 to CAU 5000. At the remaining two CASs, 12-99-10 and 15-18-01, closure activities consisted of verifying and documenting that the waste originally identified at those sites is no longer present (Appendix A).

\subsection{RECOMMENDATIONS}

Since closure activities for CAU 210 have been completed following the NDEP-approved work plan (NNSA/NSO, 2003) as documented in this report, NNSA/NSO requests the following:

1. A Notice of Completion provided by the NDEP to the NNSA/NSO for the closure of CAU 210.

2. The transfer of CAU 210 from Appendix III to Appendix IV of the FFACO Closed Corrective Action Units (FFACO, 1996). 


\subsection{REFERENCES}

BN, see Bechtel Nevada.

Bechtel Nevada. 2002. Generic Field Management Plan for Housekeeping Category Waste Sites, Las Vegas, NV.

Bechtel Nevada. 2003. Site-Specific Health and Safety Plan for Corrective Action Units 167. $210,286,390, \& 396$ Housekeeping Sites, Nevada Test Site, Nevada, Revision 1, Las Vegas, NV.

FFACO, see Federal Facility Agreement and Consent Order.

Federal Facility Agreement and Consent Order. 1996 (as amended). Agreed to by the State of Nevada, U.S. Department of Energy, and U.S. Department of Defense.

NNSA/NSO, see U.S. Department of Energy, National Nuclear Security Administration Nevada Site Office.

U.S. Department of Energy, National Nuclear Security Administration, Nevada Site Office. 2003. Sectored Clean-up Work Plan for Housekeeping Category Waste Sites, Revision 3, DOE/NV-579-REV-3, Las Vegas, NV. 
Date: June 2004 


\section{APPENDICES}


Revision: 0

Date: June 2004

\section{THIS PAGE INTENTIONALLY LEFT BLANK}




\section{APPENDIX A SECTORED HOUSEKEEPING SITE CLOSURE VERIFICATION FORMS}




\section{Sectored Housekeeping Site Closure Verification Form}

Closure Verification Date: April 5, 2004

CAU Number: 210

CAS Number: $12-99-10$

CAS Description: Storage Flatcar

Sector Designation: NTS Sector F

Housekeeping Site General Location: Area 12 Camp

Elevation: 1,597 meters $(\mathrm{m})$

Northing: 4,116,405 m (UTM Zone 11) Easting: 574,715 m (UTM Zone 11)

Latitude: 37.19111

Longitude: -116.15818

Coordinate/Elevation Data Obtained from: North American Datum, 1927.

Site Access Route: Take Mercury Highway north to Rainier Mesa Road. Turn left (northwest) on Rainier Mesa Road and proceed to Area 12 Camp. Turn right (north) on Logan Street. Turn right (northeast) again on Rainier Street. Travel to Warehouses 4 and 5 located in the northeast portion of Area 12 Camp. The "L" Yard is north of the warehouses.

\begin{tabular}{|c|c|}
\hline Waste Item(s) Originally at Site & Apparent Waste Type* \\
\hline Railroad Flatcar & None, flatcar not located. \\
\hline \multicolumn{2}{|c|}{ Ordinary, Scrap Metal, Asbestos, PCB, Salvageable, Hazardous, Radioactive, Mixed, Unknown, Other } \\
\hline No photograph available & No photograph available \\
\hline Housekeeping Site Before Closure & Housekeeping Site After Closure \\
\hline \multicolumn{2}{|c|}{$\begin{array}{l}\text { Current Site Description/Observations: The railroad flatcar was not found in the Area } 12 \text { Camp area. } \\
\text { Other railroad cars are in the vicinity but are in beneficial use for Area } 12 \text { operations. } \\
\text { X No Further Action Required at Housekeeping Site } \\
\text { Reed J.Poderis, CEM }\end{array}$} \\
\hline Corrective Action Coordinator/Designee & $\begin{array}{ll}\text { Signąture } & \text { Date }\end{array}$ \\
\hline 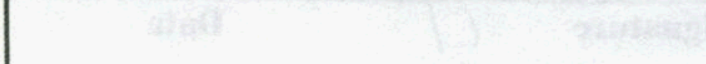 & 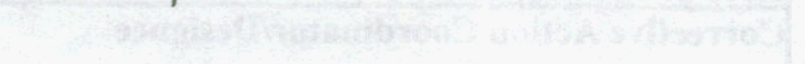 \\
\hline
\end{tabular}




\section{Sectored Housekeeping Site Closure Verification Form}

Closure Verification Date: July 10, 2003

CAU Number: 210

CAS Number: 15-18-01

CAS Description: Chemical Storage Drums (4)

Sector Designation: NTS Sector F

Housekeeping Site General Location: Area 15 Climax Mine Facility

Elevation: 1,536 meters (m)

Northing: 4,120,174 m (UTM Zone 11) Easting: 583,423 m (UTM Zone 11)

Latitude: 37.22434

Longitude: -116.05965

Coordinate/Elevation Data Obtained from: North American Datum, 1927.

Site Access Route: Take Mercury Highway north to Rainier Mesa Road. Turn left (northwest) on Rainier Mesa Road and proceed to 2-03 Road. Turn right (north) on 2-03 Road and continue to 2-05 Road and then to Circle Road. Turn left (north) on Circle Road and proceed northeast approximately 2.9 miles to 10-02 Road. Turn left (north) on 10-02 Road and proceed to the Climax Hoist. The marker is at the south side of the pad, below the ventilation conduits, and 50 feet north of the U-15e Shaft.

\begin{tabular}{|c|c|}
\hline Waste Item(s) Originally at Site & \multicolumn{1}{|c|}{ Apparent Waste Type* } \\
\hline 4 drums mounted on steel rack & None, drums previously removed. \\
\hline * Ordinary, Scrap Metal, Asbestos, PCB, Salvageable, Hazardous, Radioactive, Mixed, Unknown, Other \\
\hline \\
\end{tabular}

Current Site Description/Observations: The drums have been previously removed from the site. No evidence of staining or leakage was noted on the concrete pad below their former location.

X No Further Action Required at Housekeeping Site

Reed J. Poderis, CEM

Corrective Action Coordinator/Designee

Signature

4-26-04

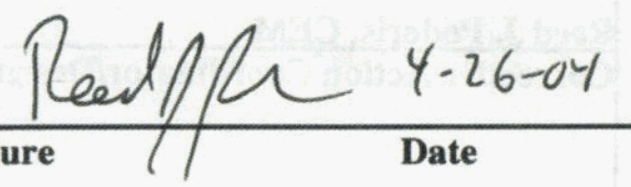




\section{APPENDIX B}

\section{NATIONAL ENVIRONMENTAL POLICY ACT EVALUATION CHECKLIST}


Closure Report - CAU 210

Section: Appendix B

Revision: 0

Date: June 2004

THIS PAGE INTENTIONALLY LEFT BLANK 


\section{U.S. DEPARTMENT OF ENERGY \\ NATIONAL NUCLEAR SECURITY ADMINISTRATION NEVADA OPERATIONS OFFICE NEPA ENVIRONMENTAL EVALUATION CHECKLIST}

\begin{tabular}{|c|l}
\hline FOLLOW ATTACHED PROCEDURES FOR COMPLETING CHECKLIST & Date \\
A. Project/Activity Title (Attach a brief description of proposed project) & $10 / 14 / 2003$ \\
\cline { 2 - 3 }
\end{tabular}

CAUs 167, 210, 289, 390, \& 395: Housekeeping Sites Closure/Cleanup Activities

\begin{tabular}{l}
\hline Project Location \\
NTS, Various Areas \\
\hline NNSA/NV Line Management Organization \\
Environmental Restoration Division \\
\hline Anticipated Start Date \\
November 1, 2003
\end{tabular}

Proposed By (If other than NNSA/NV)

NNSAVNV Project/Program Manager

Kevin Cabble/Sabine Curtis

DOE/HQ Program Office (If applicable)

ENVIRONMENTAL CONSIDERATIONS: If any phase of the project/activity involves any of the following considerations, check yes and explain in project description. See NV-16A for consideration guidelines and examples.

\begin{tabular}{|l|c|c|c|l|l|c|c|}
\hline \multicolumn{1}{|c|}{ Consideration } & Yes & No & Unk & \multicolumn{1}{|c|}{ Consideration } & Yes & No & Unk \\
\hline 1. Noise & $\mathbf{X}$ & & & 10. Liquid Effluents & & $\mathbf{X}$ & \\
\hline 2. Air Emissions & & $\mathbf{X}$ & & 11. Underground Storage/Septic Tanks & & $\mathbf{X}$ & \\
\hline 3. Explosives & & $\mathbf{X}$ & & 12. Utility Systems (PCBs) & & $\mathbf{X}$ & \\
\hline $4 . \quad$ Petroleum/Fuel Storage/Use & $\mathbf{X}$ & & & 13. Environmental Restoration Site & $\mathbf{X}$ & & \\
\hline 5. Pesticide/Herbicide Use & & $\mathbf{X}$ & & 14. Change in Existing Drainage Pattern & & $\mathbf{X}$ & \\
\hline 6. Hazardous/Toxic Substances & $\mathbf{X}$ & & & 15. Surface Disturbance/Excavation & $\mathbf{X}$ & & \\
\hline 7. Solid Waste & $\mathbf{X}$ & & & 16. Cultural/Historic Resources & & & $\mathbf{X}$ \\
\hline 8. Mixed Waste & $\mathbf{X}$ & & & 17. Biological/Tortoise Resources & & \\
\hline 9. Radioactive Materials & $\mathbf{X}$ & & & & & $\mathbf{X}$ \\
\hline
\end{tabular}

DO NOT TYPE OR WRITE BELOW THIS LINE. FOR ESHD USE ONLY.

B. Is the project/activity included in the final NTS EIS and the ROD or other NEPA document?

Yes $\mathrm{X}$ (complete Sections $\mathrm{C}, \mathrm{D}$, and E) No__ (complete Sections D, E, and F)

C. This project/activity is included in the NTS EIS/ROD (or other NEPA document) under the following section and page number:

NTS EIS Volume 1, Appendix A, A.3.1.3 - Environmental Restoration Program; Industrial Sites Project

D. Does the proposed project/activity require any local, state, or federal permits or notifications?

Yes $\underline{X} \quad$ No

E. Does the proposed project/activity relate to the FFCA or FFACO agreements? $\quad$ Yes $\mathbf{X}$ No

F. If, based on the project description and the preliminary environmental considerations noted above, the proposed action fits within a class of action listed in Subpart D of 10 CFR 1021, write in the space below, the paragraph number and short title from the appropriate table of contents of Subpart D, Appendix B, C, or D, for a CX, EA, or EIS. If the proposed action does not fit within any class of action, write "Not Listed" below.

\section{G. NEPA COMPLIANCE OFFICER DETERMINATION OR RECOMMENDATION:}

1 have determined that the proposed action as described in Item $A$ above, has been adequately addressed for the purpose of NEPA in the NTS EIS. No further analysis or documentation is required pursuant to NEPA.
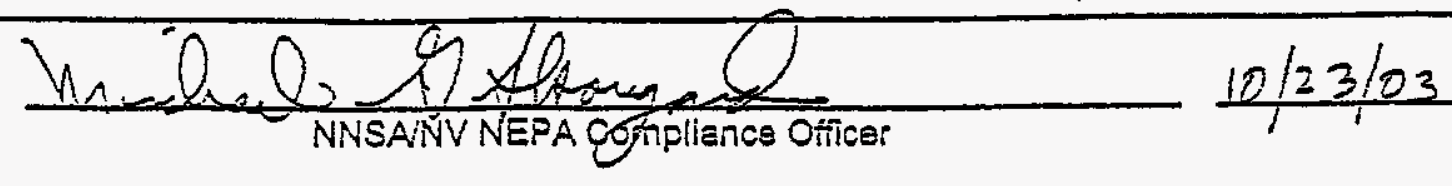


\section{CAUS 167, 210, 286, 390, \& 395: HOUSEKEEPING SITES CLOSURE/CLEANUP ACTIVITIES}

\section{Project Description}

The purpose of this project is to remove the various debris located at several Corrective Action Units (CAUs). All CAUs are housekeeping sites, located at the Nevada Test Site (NTS). CAU 167 is located in Areas 5, 18, and 19 and consists of four Corrective Action Sites (CASs). CAU 210 is located in Areas 10, 12 and 15 and consists of 4 CASs. CAU 286 is located in Areas 1,2,3,4, and 6 and consists of twelve CASs. CAU 390 is located in Areas 9, 10, and 12 and consists of six CASs. CAU 395 is located in Area 19 and consists of ten CASs. A detailed list of the CASs and descriptions is provided in the FFACO (1996). Each CAU is listed below, with a brief description of the types of debris present in the CASs.

\section{CAU 167}

Includes approximately 40 boxes of rock cores, stained soil below a disabled combat tank, and a trash pit with metal and wood debris. Some of the rock cores and the soil below the combat tank are possibly radioactive.

\section{CAU 210}

Includes several empty metal cans and buckets and a large piece of scrap metal. The large piece of scrap metal may be radioactive.

\section{CAU 286}

Includes primarily pieces of lead shielding in various locations. A pile of concrete is also included. Some of the wastes may be radioactive. The lead material is hazardous. However, the majority of the lead material is salvageable.

\section{$\underline{\mathrm{CAU}} 390$}

Includes asphalt, paraffin wax, and tar spills. One drum with several gallons of unknown liquid is also included. Some of the waste may be radioactive and or hazardous/toxic.

\section{CAU 395}

Includes concrete, oil, and asphalt spills. Several spills of unidentified materials are also included. Some of the waste may be radioactive and or hazardous/toxic.

\section{Environmental Considerations}

1. Noise levels: Elevated noise levels may result from the operation of a backhoe and/or loader equipment. Personnel not directly involved with operation of this equipment will be kept back at least 15 feet while equipment is in use. The equipment operator will follow the instructions as directed in the Site Specific Health and Safety Plan.

4. Petroleum/Fuel Storage Use: Heavy equipment on site will use petroleum fuel. No fuel will be stored on site outside of the equipment. Absorbent pads will be used if equipment appears to be leaking petroleum.

6. Hazardous/Toxic Substances: Several sites contain lead, PCB or TPH-impacted and/or sanitary waste and soil. No other chemical hazards are known to exist. Personnel will be required to follow the safety procedures outlined in the Site Specific Health and Safety Plan and Job Hazard Analysis. Wastes will be disposed of either on the NTS or offsite, depending on analysis results.

7. Solid Waste: Any solid waste that may be generated from project activities will be disposed of at the NTS in a designated landfill.

8. Mixed Waste: Any waste which is classified as a mixed waste will be disposed of at the NTS in a approved mixed waste facility.

9. Radioactive Materials: Several sites are in a URMA, CA, or RMA. Radiologically-impacted soil and manufactured items in these areas may require disposal at either the Area 3 or Area 5 Radioactive Waste Management Site.

13. Environmental Restoration Site: These sites are included in the FFACO as Corrective Action Units $167,210,286,390$ and 395. (See Project Description). 
- 15. Surface Disturbance/Excavation: Equipment will travel off-road on previously disturbed areas. Equipment will also be used to help remove surface debris. Minor excavations may be required to removed stained soil at spill locations. All excavations will be performed under the appropriate permit.

- 16. Cultural/Historic Resources: Two sites contain equipment and/or structures which may be designated as a historic artifact from NTS operations. Cultural surveys will be conducted as necessary at these sites as well as any of the other sites prior to project activities.

17. Biological/Tortoise Resources: Biological pre-activity surveys may be required in areas where off-road travel or excavation will occur. Surveys will be conducted prior to any surface-disturbing activities. 


\section{APPENDIX C}

\section{CORRECTIVE ACTION UNIT 210 FFACO MODIFICATION COORESPONDENCE}


Revision: 0

Date: June 2004

$-$ 
Closure Report - CAU 210

Section: Appendix C

Revision: 0

Date: June 2004

\section{FFACO COORESPONDENCE FOR}

\section{CAS 10-23-01 (METAL DEBRIS; RAD)}


Revision: 0

Date: June 2004

\section{THIS PAGE INTENTIONALLY LEFT BLANK}


.

AI.J.F. BIACGI, AUdministrutor

Adm:inistration

Witer P'sllution Control

Air Cuality:

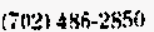

STATE OF NEVADA KENNY C. GUINN Gionernor

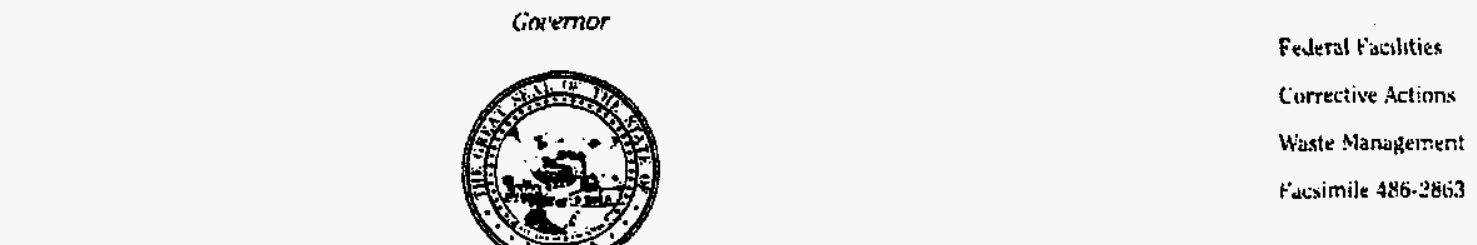

\section{DIVISION OF ENVIRONMENTAL PROTECTION}

(Las Vegas Office)

1771 E. Flamingo Road, Suite 121-A

Las Vegas, Nevada $89119-0837$

April 15, 2004

Ms. Janet Appenzeller-Wing

Acting Director, Environmental Restoration Division

Nuclear Security Administration

Nevada Site Office

P. O. Box 98518

Las Vegas, NV 89193-8518

RE: Approval of REQUEST TO TRANFSFER CORRECTIVE ACTION SITES (CAS) 18-99-08 AND 10-23-01 TO CORRECTIVE ACTION UNIT (CAU) 286, LEAD/CHEMICAL/SPILL SITES AND MATERIAL DUMPS

Dear Ms. Appenzeller-Wing:

The Nevada Division of Environmental Protection, Bureau of Federal Facilities (NDEP) staff has reviewed the request to transfer Corrective Action Sites (CAS) 18-99-08, Core in Boxes, located in CAU 167, Contaminated Materials and Trash Pits, and CAS 10-23-01, Metal Debris (RAD), located in CAU 210, Storage Areas and Contaminated Material, to CAU 286, Lead/Chemical/Spill Sites and Material Dumps. The request is hereby approved.

If you have any questions regarding this matter, direct them to Karen Beckley at (775) 687-9390, or Marcia Manley at (775) 687-9309.

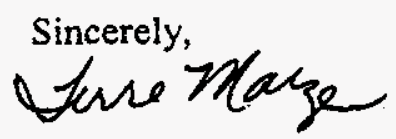

Terre A. Maize.

Chief

Bureau of Federal Facilities

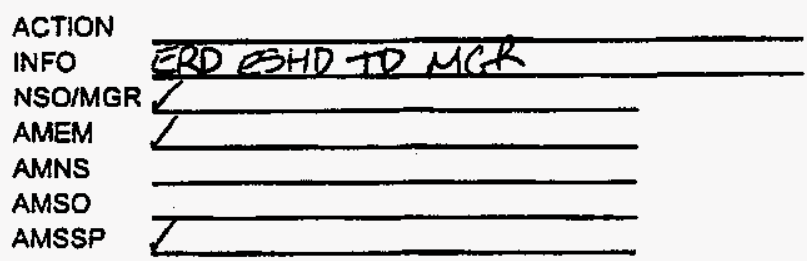


Ms. Appenzeller-Wing

April 15, 2004

Page 2

\section{TAM/MAM/KKB/DRE/mm}

cc: Don Elle, NDEP LV

Karen Beckley, NDEP CC

S.M. Doty, EM Records Center, NNSANSO,

Las Vegas, NV

E.E. Shanholtz, DTRA/TDTNS, M/S 645, Mercury, NV

LTC P.M. Loomis, USA, DTRA/TDTNS, M/S 645, Mercury, NV

D.C. Loewer, DTRA/TDTNS, M/S 645, Mercury, NV

T.A. Lantow, DTRA/TDTNS, M/S 645, Mercury, NV

W.R. Griffin, BN/DTRA, M/S 645, Mercury, NV

R.L. Brittigan, DTRA/GC, Ft. Belvoir, VA

M.A. Demcko, DTRA/ALHK, Kirkland AFB, NM

J.L. Smith, BN, Mercury, NV

B.S. Bailey, S-N, M/S 439, Las Vegas, NV

B.C. Hoenes, S-N, M/S 439, Las Vegas, NV

G.M. Romano, S-N, M/S 439, Las Vegas, NV

K.A. Hoar, ESHD, NNSANSSO, Las Vegas, NV

S.T. Curtis, ERD, NNSANSO, Las Vegas, NV

P.L. Hall, TD, NNSA/NSO, Las Vegas, NV 
ALLEN BLAGGI, Administrator

Administration

Water Pollution Control

Air Quality

(702) 486-285i)
STATE OF NEVADA

KENNY C. CUINN

Goternor

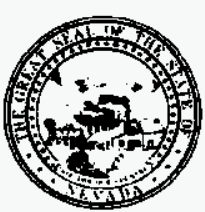

DEPARTMENT OF CONSERVATION AND NATURAL RESOURCES

DIVISION OF ENVIRONMENTAL PROTECTION

(Las Vegas Office)

1771 E. Flamingo Road, Suite 121-A

Las Vegas, Nevada 89119-0837

May 24, 2004
R. MICHAE.T, TURNIPSEED, Director

Federal Facilities

Corrective Actions

Waste Management

Facsimile $4 \times 6-2863$

Monica L. Sanchez. Acting Director

Environmental Restoration Division

National Nuclear Security Administration

Nevada Site Office

P.O. Box 98518

Las Vegas, NV 89193-8518

Re: REQUEST TO TRANSFER CORRECTIVE ACTION SITES (CASs) 12-28-03, $02-$ 26-07 and 18-99-06 TO CORRECTIVE ACTION UNIT (CAU) 5000, ARCHIVED CORRECTIVE ACTION SITES

Dear Ms. Sanchez:

The Nevada Division of Environmental Protection, Bureau of Federal Facilities (NDEP) staff reviewed the additional information provided regarding this request to transfer three CASs to CAU 5000. Based on this review, NDEP agrees with the request to transfer the sites to CAU 5000.

If there are questions regarding this matter, please contact Don Elle at (702) 486-2874.

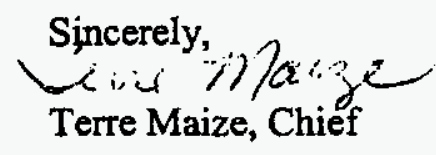

TM/DRE

cc: Ken Hoar, Director, ES\&HD, NNSA/NSO

Eric Shanholtz, Dhief, DTRA

Patti Hall, EM, NNSA/NSO

Wayne Griffin, BN/DTRA

Tiffany Lantow, DTRA/YDTON

Janet Appenzeller-Wing, kERD,NNSA/NSO

S. T. Curtis, ERD, NNSA/NSO

Karen Beckley, NDEP-CC

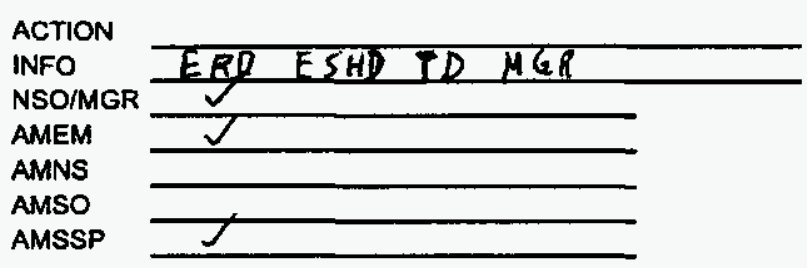


-

س -

$-$

-

무

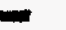

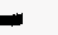

. 
Closure Report - CAU 210

Section: Distribution List

Revision: 0

Date: June 2004

\section{LIBRARY DISTRIBUTION LIST}


Date: June 2004

THIS PAGE INTENTIONALLY LEFT BLANK 


\section{LIBRARY DISTRIBUTION LIST}

Southern Nevada Public Reading Facility

c/o Nuclear Testing Archive

P.O. Box 98521 , M/S 400

Las Vegas, NV 89193-8521

U.S. Department of Energy

National Nuclear Security Administration Nevada Site Office

Technical Library

P.O. Box 98518, M/S 505

Las Vegas, NV 89193-8518

U.S. Department of Energy

Office of Scientific and Technical Information

P.O. Box 62

Oak Ridge, TN 37831-0062

Manager, Northern Nevada FFACO

Public Reading Facility

c/o Nevada State Library and Archives

100 North Stewart Street

Carson City, NV 89701-4285
1 (Controlled) \&

1 (Uncontrolled)

1 (Uncontrolled) 
Revision: 0

Date: June 2004 